\title{
Allergen and Epitope Targets of Mouse-Specific T Cell Responses in Allergy and Asthma
}

\section{Véronique Schulten ${ }^{*}$, Luise Westernberg ${ }^{1}$, Giovanni Birrueta ${ }^{1}$, John Sidney', Sinu Paul', Paula Busse ${ }^{2}$, Bjoern Peters ${ }^{1,3}$ and Alessandro Sette ${ }^{1,3}$}

${ }^{1}$ La Jolla Institute for Allergy and Immunology, La Jolla, CA, United States, ${ }^{2}$ Division of Clinical Immunology, Icahn School of Medicine at Mount Sinai, New York, NY, United States, ${ }^{3}$ Department of Medicine, University of California San Diego, La Jolla, CA, United States

Mouse allergy has become increasingly common, mainly affecting laboratory workers and inner-city households. To date, only one major allergen, namely Mus m 1, has been described. We sought to identify $T$ cell targets in mouse allergic patients. PBMC from allergic donors were expanded with either murine urine or epithelial extract and subsequently screened for cytokine production (IL-5 and IFN $\gamma$ ) in response to overlapping peptides spanning the entire Mus $\mathrm{m} 1$ sequence, peptides from various Mus $\mathrm{m} 1$ isoforms [major urinary proteins (MUPs)], peptides from mouse orthologs of known allergens from other mammalian species and peptides from proteins identified by immunoproteomic analysis of lgE/lgG immunoblots of mouse urine and epithelial extracts. This approach let to the identification of 106 non-redundant $T$ cell epitopes derived from 35 antigens. Three major T cell-activating regions were defined in Mus $\mathrm{m} 1$ alone. Moreover, our data show that immunodominant epitopes were largely shared between Mus $\mathrm{m} 1$ and other MUPs even from different species, suggesting that sequence conservation in different allergens is a determinant for immunodominance. We further identified several novel mouse $T$ cell antigens based on their homology to known mammalian allergens. Analysis of cohort-specific T cell responses revealed that rhinitis and asthmatic patients recognized different epitope repertoires. Epitopes defined herein can be formulated into an epitope "megapool" used to diagnose mouse allergy and study mouse-specific T cell responses directly ex vivo. This analysis of $T$ cell epitopes provides a good basis for future studies to increase our understanding of the immunopathology associated with MO-allergy and asthma.

\section{Keywords: mouse allergy, asthma, $\mathrm{T}$ cell epitope, Mus $\mathrm{m} 1$, allergic rhinitis}

\section{SIGNIFICANCE STATEMENT}

Allergic Sensitization to mouse is a strong risk factor for the development of asthmatic disease, yet little is known about the allergic $\mathrm{T}$ cell response to mouse. We have identified 106 non-redundant epitopes from 35 distinct antigens targeted by $\mathrm{T}$ cells. Disease cohort-specific analysis revealed that asthmatic patients recognize a broader epitope repertoire compared to rhinitic patients. The identification of $\mathrm{T}$ cell epitopes in mouse allergy reveals an immuodominant set of peptides that can be exploited for the detection of mouse-specific $\mathrm{T}$ cells ex vivo, revealing $\mathrm{T}$ cell phenotypes associated with different degrees of disease severity. 


\section{INTRODUCTION}

Mouse (MO) allergies are of growing importance in children and adults alike as they are potent sensitizers (1) and MO allergies are prevalent in the United States, especially in inner city populations (2,3). A study of children in American inner cities reported that $18 \%$ have positive mouse skin test responses (1). Similarly, prevalence of mouse sensitization of $10-26 \%$ have been reported $(4,5)$ in cohorts of animal-care workers, exposed to $\mathrm{MO}$ allergens because of occupational duties. The clinical relevance of MO allergies is underlined by several studies indicating that MO-sensitization is a strong correlate of asthma development (6, 7). MO-specific IgE is associated with early wheeze and atopy in inner-city birth cohorts. The odds ratio for onset of wheezing by age 3 is 4.6 for MO-sensitized children and remarkably rises to 9.7 in children cosensitized to $\mathrm{MO}$ and cockroach (6), another pestrelated allergy commonly found in inner cities. Furthermore, high IgE titers to $\mathrm{MO}$ and to German cockroach (CR) have also been associated with atopic dermatitis (6).

Despite their clinical and epidemiological importance, little is known about MO allergens at the molecular level. Studies on occupational allergies to small rodents and their molecular triggers date back several decades $(8,9)$. Sources of MO allergens include epithelium (10), urine (11), serum (12) saliva (13), hair and dander. Urine is the most potent source of MO allergens, since rodents have permanent proteinuria and are behaviorally prone to spray urine on their surroundings (especially males which have higher protein concentrations in urine). When urine dries up, proteins associate with airborne dust particles and can be inhaled, leading to sensitization.

Today, only one mouse allergen is listed in the IUIS database (14), namely Mus m 1, a major urinary protein (MUP) that belongs to the lipocalin superfamily (15). MUPs are encoded by a multigene family (Mup genes) and 8-14 MUPs are typically detected in a single adult mouse (16). The lipocalin superfamily includes several well-conserved mammalian allergens, including the major rat allergen Rat $\mathrm{n} 1, \operatorname{dog}$ allergens Can $\mathrm{f} 1$ and 2, horse allergen Equ c 1, cockroach allergen Bla g 4, and others (15).

Immunological studies of the molecular targets recognized by $\mathrm{MO}$ allergen-specific $\mathrm{T}$ cells are virtually non-existent. Over a decade ago, Jeal et al. performed a comprehensive $\mathrm{T}$ cell epitope mapping of the major rat allergen Rat n 1 (17), and epitopes have also been defined for Bla g 4 (18). In contrast, a query in the immune epitope database (IEDB) (19), a free resource that curates published human $\mathrm{T}$ cell epitopes for allergies and other diseases, only returned a single $\mathrm{T}$ cell epitope for mouse allergy published by Ferrari et al. (20). Therefore, we sought to fill this knowledge gap by identifying $\mathrm{T}$ cell epitopes recognized by MO-allergic individuals.

Moreover, it is currently unclear whether Mus m 1 is the only relevant $\mathrm{MO}$ allergen, or if other proteins are also of importance especially when $\mathrm{T}$ cell responses are considered. Indeed, mouse serum albumin has also been reported to have allergenic potential (12), though it is not officially listed in the IUIS. To address the question of whether, in addition to Mus $\mathrm{m} 1$, other relevant $\mathrm{T}$ cell targets can be defined, we studied Mus $\mathrm{m} 1$ isoforms/homologs, mouse homologs of mammalian allergens, and performed a broad immunoproteomic analysis of urine and epithelial extracts.

\section{MATERIALS AND METHODS}

\section{Study Population and PBMC Isolation}

A cohort of $22 \mathrm{MO}$-sensitized patients and $10 \mathrm{MO}$-non-allergic, but MO-exposed patients, as defined by mouse-specific IgE titers of $>0.35 \mathrm{kU}_{\mathrm{A}} / \mathrm{L}$ was studied. Patients were recruited from San Diego, CA, and New York City, NY, following Institutional Review Board approval (IRB protocols: VD-112-0217, GCO 13-0691). All patients enrolled in this study provided written consent. Clinical information is summarized in Table 1. The cohort was $59 \%$ female, with an age range of 23-61 years. IgE-titers were determined from plasma using the ImmunoCAP (Thermo Fischer, Uppsala, Sweden). PBMCs were isolated from whole blood by density gradient centrifugation according to manufacturers' instructions (Ficoll-Hypaque, Amersham Biosciences, Uppsala, Sweden).

\section{Selection of Peptides from Known Mouse and Other Mammalian Allergens}

Sequences of two isoforms of the mouse allergen, Mus $\mathrm{m} 1$ [Mus m 1.0101 and Mus m 1.0102, known as Mup 6 and Mup

TABLE 1 | Clinical and demographic data for all donor cohorts.

\begin{tabular}{|c|c|c|c|c|c|}
\hline Donor & Birth year & Gender & $\begin{array}{l}\text { Clinical } \\
\text { status }\end{array}$ & $\begin{array}{c}\text { Mouse IgE } \\
\qquad\left(\mathrm{kU}_{\mathrm{A}} / \mathrm{L}\right)\end{array}$ & $\begin{array}{l}\text { In vitro } \\
\text { stimulus }\end{array}$ \\
\hline 1011 & 1979 & $M$ & Asthma & 3.13 & Urine \\
\hline 1209 & 1974 & $\mathrm{~F}$ & Asthma & 3.09 & Urine \\
\hline 1277 & 1965 & $M$ & Asthma & 5.24 & Urine \\
\hline 1284 & 1984 & $F$ & Asthma & 2.71 & Urine \\
\hline 1368 & 1994 & $M$ & Asthma & 14.80 & Epithelium \\
\hline 1424 & 1988 & $\mathrm{~F}$ & Asthma & 57.60 & Urine \\
\hline 1425 & 1979 & $\mathrm{~F}$ & Asthma & 4.89 & Urine \\
\hline 1435 & 1978 & $M$ & Asthma & 9.01 & Urine \\
\hline 1437 & 1980 & $F$ & Asthma & 13.40 & Urine \\
\hline 1440 & 1989 & $M$ & Asthma & 2.14 & Epithelium \\
\hline 1441 & 1971 & $M$ & Asthma & 2.93 & Urine \\
\hline 1460 & 1984 & $M$ & Rhinitis & 2.49 & Urine \\
\hline 1463 & 1993 & $M$ & Asthma & 4.90 & Urine \\
\hline 1600 & 1992 & $\mathrm{~F}$ & Rhinitis & 1.02 & Epithelium \\
\hline 1704 & 1985 & $\mathrm{~F}$ & Rhinitis & 2.02 & Urine \\
\hline 1726 & 1986 & $\mathrm{~F}$ & Asthma & 2.68 & Epithelium \\
\hline 2017 & 1994 & $\mathrm{M}$ & ND & 2.21 & Urine \\
\hline 2397 & 1956 & $\mathrm{~F}$ & Asthma & 1.08 & Epith \\
\hline 2414 & 1979 & $\mathrm{~F}$ & Rhinitis & 4.86 & Epithelium \\
\hline 2423 & 1956 & $\mathrm{~F}$ & Rhinitis & 0.71 & Epithelium \\
\hline 2424 & 1980 & $\mathrm{~F}$ & Rhinitis & 1.29 & Epithelium \\
\hline 2489 & 1990 & $\mathrm{~F}$ & Rhinitis & 11.00 & Urine \\
\hline 1774 & 1985 & $\mathrm{~F}$ & Non-allergic & $<0.1$ & $\mathrm{n} / \mathrm{a}$ \\
\hline 2015 & 1987 & $M$ & Non-allergic & $<0.1$ & $\mathrm{n} / \mathrm{a}$ \\
\hline 2458 & 1982 & $\mathrm{~F}$ & Non-allergic & $<0.1$ & $\mathrm{n} / \mathrm{a}$ \\
\hline 2491 & 1992 & $M$ & Non-allergic & $<0.1$ & $\mathrm{n} / \mathrm{a}$ \\
\hline 2500 & 1981 & $\mathrm{~F}$ & Non-allergic & $<0.1$ & $\mathrm{n} / \mathrm{a}$ \\
\hline 2501 & 1992 & $M$ & Non-allergic & $<0.1$ & $\mathrm{n} / \mathrm{a}$ \\
\hline 2503 & 1979 & $F$ & Non-allergic & $<0.1$ & $\mathrm{n} / \mathrm{a}$ \\
\hline 2544 & 1991 & $\mathrm{~F}$ & Non-allergic & $<0.1$ & $\mathrm{n} / \mathrm{a}$ \\
\hline 2547 & 1992 & $\mathrm{~F}$ & Non-allergic & $<0.1$ & $\mathrm{n} / \mathrm{a}$ \\
\hline 2555 & 1989 & $\mathrm{M}$ & Non-allergic & $<0.1$ & $\mathrm{n} / \mathrm{a}$ \\
\hline
\end{tabular}


2, respectively] (14) were collected from UniProt. The two sequences were aligned using MEGA software tool (21). 15mer peptides overlapping by 10 amino acids were generated to get the full coverage of both sequences. This peptide set included 34 peptides (peptide set \#1, Figure S1 in Supplementary Material).

An additional set of twenty mouse urinary proteins was collected from GenBank and aligned with the Mup 6 and Mup 2 proteins. 15 mer peptides overlapping by 10 amino acids were generated and a total of 172 additional peptides not included in the set of 34 peptides above were selected from this alignment. These 172 peptides were further screened for their predicted binding affinity as described in Paul et al. (22). A set of 48 additional Mus m 1-isoform -derived peptides with high binding affinity was selected (peptide set \#2, Figure S1 in Supplementary Material).

The WHO/IUIS database (14) was screened for major mammalian allergens, and their sequences were blasted against the mouse genome (NCBI Protein Database). Thirty-one murine protein sequences homologous to known allergens from mammals were collected from GenBank using NCBI BLAST. A total of 244 peptides from 20 different proteins (Table S1 in Supplementary Material) were selected based on predicted binding affinity (22) and redundancy elimination (peptide set \#3, Figure S1 in Supplementary Material). In addition, we selected the 244 corresponding mammalian peptides homologous to these murine peptides, to be used to evaluate specificity of responses (peptide set \#4, Figure S1 in Supplementary Material). Some of the mouse sequences did not have corresponding regions in the mammalian allergen sequences because of sequence divergence and therefore the most identical peptides were selected.

\section{Selection of Peptides from Immunoproteomic Analysis}

Methods for performing a 2-D immunoblot analysis to determine IgE and IgG reactivity have previously been described for cockroach (18) and Timothy grass (23) allergens. Briefly, urine and epithelia MO extracts $(300 \mu \mathrm{g})$ were run on separate $2-\mathrm{D}$ gels [3-10 pH range, 12\% 138 ( vol/vol) acrylamide] at Applied Biomics (Hayward, CA, USA). Subsequently, gels were blotted and the 2-D immunoblots were incubated with pooled plasma (diluted 1:50) from nine MO allergic donors (mouse IgE titers ranging from 4.9-56.7 kU/L) recruited in San Diego. Next, blots were incubated with goat antihuman IgE and mouse anti-human IgG (Sigma-Aldrich, Carlsbad, CA, USA), and MO donor antibody reactivity visualized using Cy2-conjugated donkey antigoat IgG and Cy5-conjugated donkey anti-mouse IgG antibodies (Biotium, Fremont, CA, USA). We then determined the antibody reactivity of each spot by visual inspection of the 2-D immunoblot images. In total, 106 and $32 \mathrm{IgE}$ and/or IgG-reactive protein spots for epithelial and urine extract were selected, respectively. Spots were cut out of gels run in parallel to the gels that were blotted. The cut out spots were analyzed by mass spectrometry. Proteins were identified by comparing the MS/MS spectral data to the mouse transcriptome using Mascot software (Matrix Science, Boston, MA, USA). The mass-spectrometry studies identified a total of 25 sequences from epithelial and 9 from urine extract. After redundancy elimination, a total of 23 proteins in the mouse epithelial extract gel not already covered by known allergen sequences described above were broken down to 1,356 peptides of 15 mers size overlapping by 10 amino acids. A total of 307 peptides were selected based on the predicted binding affinity as described (22). Likewise, we observed nine proteins in the mouse urine gel of which four were already covered by peptides from the previous peptide sets. The remaining five proteins were again broken down to 15 mers overlapping by 10 amino acids and a total of 85 predicted HLA class II binder peptides were thus selected from these proteins.

\section{Urine and Epithelia MO Extracts}

Mouse epithelial extract was purchased from Greer (Lenoir, NC, USA). Mouse urine (mixed gender pooled, unfiltered) was purchased from CliniScinces (Nanterre, France). Low molecular components $(<3 \mathrm{kDa})$ were removed by filtration centrifugation using Amicon Ultracel tubes (Merck Millipore, Darmstadt, Germany). The high-molecular-weight fraction $(>3 \mathrm{kDa})$ was washed six times with PBS, each time followed by repeated centrifugation in Amicon Ultracel tubes with a cutoff of $3 \mathrm{kDa}$. The resulting urine extract was lyophilized and subsequently resuspended in PBS at $20 \mathrm{mg} / \mathrm{ml}$ (confirmed by BCA assay).

\section{HLA Typing and Inferred Restrictions}

HLA typing for Class I (HLA-A; HLA-B; HLA-C) and Class II (HLA-DQA1; HLA-DQB1, HLA-DRB1,3,4,5; HLA-DPB1) was performed by an ASHI-accredited (American society for histocompatibility and immunogenetics) laboratory at Murdoch University (Western Australia) as previously described (24). Potential HLA-epitope restriction odds ratios and relative frequencies were calculated using the RATE program (25). To further filter identified inferred restrictions, HLA class II binding predictions were performed for peptide restrictions inferred by the RATE program, as recommended by the IEDB (19).

\section{Peptide Synthesis}

Peptides were purchased from A and A (San Diego, CA, USA) as crude material on a small $(1 \mathrm{mg})$ scale. Individual peptides were resuspended in DMSO at a final concentration of $40 \mathrm{mg} / \mathrm{ml}$.

\section{Stimulation and Expansion of MO-Specific T Cells with Urine or Epithelia MO Extracts}

For in vitro expansion of mouse-specific T cells, PBMCs of MO-sensitized individuals were stimulated with either epithelial $(60 \mu \mathrm{g} / \mathrm{ml})$ or urine extracts $(3 \mu \mathrm{g} / \mathrm{ml})$. Stimulation concentrations to induce optimal $\mathrm{T}$ cell responses were previously determined by titration (data not shown). Cells were cultured in RPMI 1640 supplemented with $5 \%$ human $\mathrm{AB}$ serum in 24 -well plates (BD Bioscience, San Diego, CA, USA) at a density of $2 \times 10^{6} / \mathrm{ml}$ and incubated at $37^{\circ} \mathrm{C}$. IL-2 was added every 3 days after initial stimulation. Cells were harvested on day 14 and screened for IFN $\gamma$ and IL-5-production by ELISPOT.

\section{Dual ELISPOT Assays}

The production of IFN $\gamma$ and IL-5 from cultured PBMCs in response to antigenic stimulation was assessed by dual ELISPOT assays as described previously (26). Cells $\left(1 \times 10^{5}\right.$ cells/well $)$ were stimulated with either peptide pools $(5 \mu \mathrm{g} / \mathrm{ml})$, individual peptides 
(10 $\mu \mathrm{g} / \mathrm{ml})$, or MO extracts $(2 \mu \mathrm{g} / \mathrm{ml}$ each), PHA $(10 \mu \mathrm{g} / \mathrm{ml})$, or medium containing $0.25 \%$ DMSO (\% of DMSO in the pools/ peptides) as a control. Spot forming cells (SFC) were counted by computer assisted image analysis (KS-ELISPOT reader, Zeiss, Munich, Germany). T cell responses were backgroundsubtracted and expressed per $10^{6}$ cells. Criteria for positivity were $\geq 20$ SFCs per $10^{6}$ PBMCs, $p<0.05$, and a stimulation index $\geq 2$. Any responses that did not meet these criteria were set to 20 SFC, which is considered the sensitivity threshold for this assay. Positive pools ( $\geq 100 \mathrm{SFC}$ ) were deconvoluted to identify the individual epitopes inducing the response.

\section{Antigen-Reactive T Cell Enrichment (ARTE) Assay}

Ex vivo $\mathrm{T}$ cell responses were measured based on $\mathrm{T}$ cell activation and cytokine production as previously described by Bacher et al. (27). Briefly, PBMC were thawed and rested overnight, plated at $10 \times 10^{6}$ cells per well in a six-well plate. The next morning, cells were stimulated with urine $(3 \mu \mathrm{g} / \mathrm{ml})$, epithelial extract $(60 \mu \mathrm{g} / \mathrm{ml})$, peptide megapool $(2 \mu \mathrm{g} / \mathrm{ml})$, phorbol myristate acetate and Ionomycin (Io) (positive control), or medium alone (negative control) in the presence of $1 \mu \mathrm{g} / \mathrm{ml} \mathrm{CD} 40$ (Miltenyi Biotech, Auburn, CA, USA). Cells were incubated for $6 \mathrm{~h}$, adding Brefeldin A $(1 \mu \mathrm{g} / \mathrm{ml})$ for the last $3 \mathrm{~h}$. After the incubation, cells were labeled with antiCD154-Biotin, anti-CD4 APC ef780, CD3 AF700, anti-CRTH2 Ax647, CD8/CD14/CD19 V500 and live/dead fixable viability dye (Life technologies, San Diego, CA, USA) followed by anti-Biotin MicroBeads (Miltenyi Biotech, Auburn, CA, USA). After staining and washing, CD154 + cells were magnetically enriched using MS columns (Miltenyi Biotech, Auburn, CA, USA). Fixation, permeabilization and intracellular staining was performed on the column using the Inside stain kit (Miltenyi Biotech, Auburn, CA, USA), anti-IL-4 BV421, IFN $\gamma$ PerCPCy.5.5, anti-IL-10 AF488, anti-IL-17 PECy7, and CD154 PE (BD, San Diego, CA, USA). Finally, cells were elusted off the column and analyzed by flow cytometry using a BD LSR II flow cytometer and data were analyzed using FlowJo software (TreeStar, Ashland, OR, USA). All data acquisition was performed blinded.

\section{RESULTS}

\section{Mus m 1-Derived Immunodominant T Cell Epitopes}

To compare potencies of epithelial and urine extracts to expand $\mathrm{MO}$-specific $\mathrm{T}$ cells from allergic donors in vitro, we measured extract-specific IL-5 and IFN $\gamma$ production by ELISPOT in urine ( $n=15)$ or epithelial $(n=17)$ expanded cells following $24 \mathrm{~h}$ restimulation with the extract used for expansion. Overall, both extracts expanded $\mathrm{T}$ cells with similar efficiency (Figure 1A). While both extract responses were dominated by IL-5, this polarization was most pronounced for urine extract, while significantly higher IFN $\gamma$ production was observed in response to the epithelial extract.

To define Mus m $1 \mathrm{~T}$ cell epitopes recognized in MO allergic individuals, PBMC from allergic donors were expanded with either urine or epithelial extracts, and cytokine responses (IL-5 and IFN $\gamma$ ) were determined following $24 \mathrm{~h}$ restimulation using overlapping peptides spanning the entire Mus $\mathrm{m} 1$ sequence. Not surprisingly, the urine extract was more efficient in expanding cells responding to restimulation with Mus $\mathrm{m} 1$ as compared to the epithelial extract. However, the epitopes recognized after short-term restimulation following epithelial extract only comprise a fraction of those recognized after urine expansion (Figures 1B-C) and reactivity after epithelial expansion was lower overall compared to urine. The combined data from all 22 allergic donors tested (8 epithelial expanded, 14 urine expanded) revealed seven dominant Mus $\mathrm{m} 1$ epitopes (defined as those with magnitude of $\geq 200$ SFC and/or frequency $\geq 20 \%$ ) (Figure 1D), corresponding to three main $\mathrm{T}$ cell-reactive regions.

\section{Conservation of Mus $\mathrm{m} 1$ within Mouse and Other Rodents Is a Determinant of Immunodominance}

Mouse Urinary Proteins (MUPs) include several Mus $\mathrm{m} 1$ isoforms, and other highly related proteins. A comprehensive panel of 48 peptides derived from various MUPs with a high predicted binding affinity to MHC molecules (22) was screened by ELISPOT following urine $(n=14)$ or epithelial $(n=8)$ extract expansion. In ten instances, responses were detected against both the Mus $\mathrm{m} 1$ peptide and a homologous isoform version (Table S2 in Supplementary Material). Seven of those ten instances corresponded to the seven immunodominant peptides identified above (Figure 1D). This suggests that sequence conservation in different allergens is a determinant for immunodominance, as previously reported in pollens and other systems (28).

Next, the data derived from screening of all MUPs as a whole, including Mus m 1, was further analyzed (Figures 2A,B). Peptides for which $\mathrm{T}$ cell reactivity was observed against both Mus $\mathrm{m} 1$ and the homologous isoform peptide were defined as "shared." Peptides with $\mathrm{T}$ cell reactivity only against either the Mus $\mathrm{m} 1$ or the isoform peptide were defined as "unique." We found that shared peptides elicit significantly higher $\mathrm{T}$ cell responses compared to unique peptides. Out of $42 \mathrm{~T}$ cell epitopes, 29 peptides were shared, and 13 peptides were unique, compared to the total peptide set tested which contained 41 shared peptides and 41 unique peptides (one-sided Fisher's exact test $p=0.03$ ). These results confirmed that isoform conservation is a major determinant of immunodominance within MUPs.

A previous study reported a set of $19 \mathrm{~T}$ cell epitopes (17) from the major rat allergen, Rat n 1, also a MUP with significant homology to Mus m1. Here, the IEDB epitope clustering tool (Dhanda et al., submitted) was used to identify T cell-reactive peptides conserved between Mus $\mathrm{m} 1$ and Rat $\mathrm{n} 1$ (Table S3 in Supplementary Material). Eight of the 20 Mus $\mathrm{m} 1$ epitopes clustered with Rat $\mathrm{n} 1$ epitopes at the 70\% homology threshold. Six of those eight are among the top nine epitopes in terms of strength of reactivity. This association is statistically significant ( $p=0.023$ by Fisher's exact test, one-tailed). This finding supports the notion that peptides conserved in other rodent species elicit a more dominant immune response, possibly due 

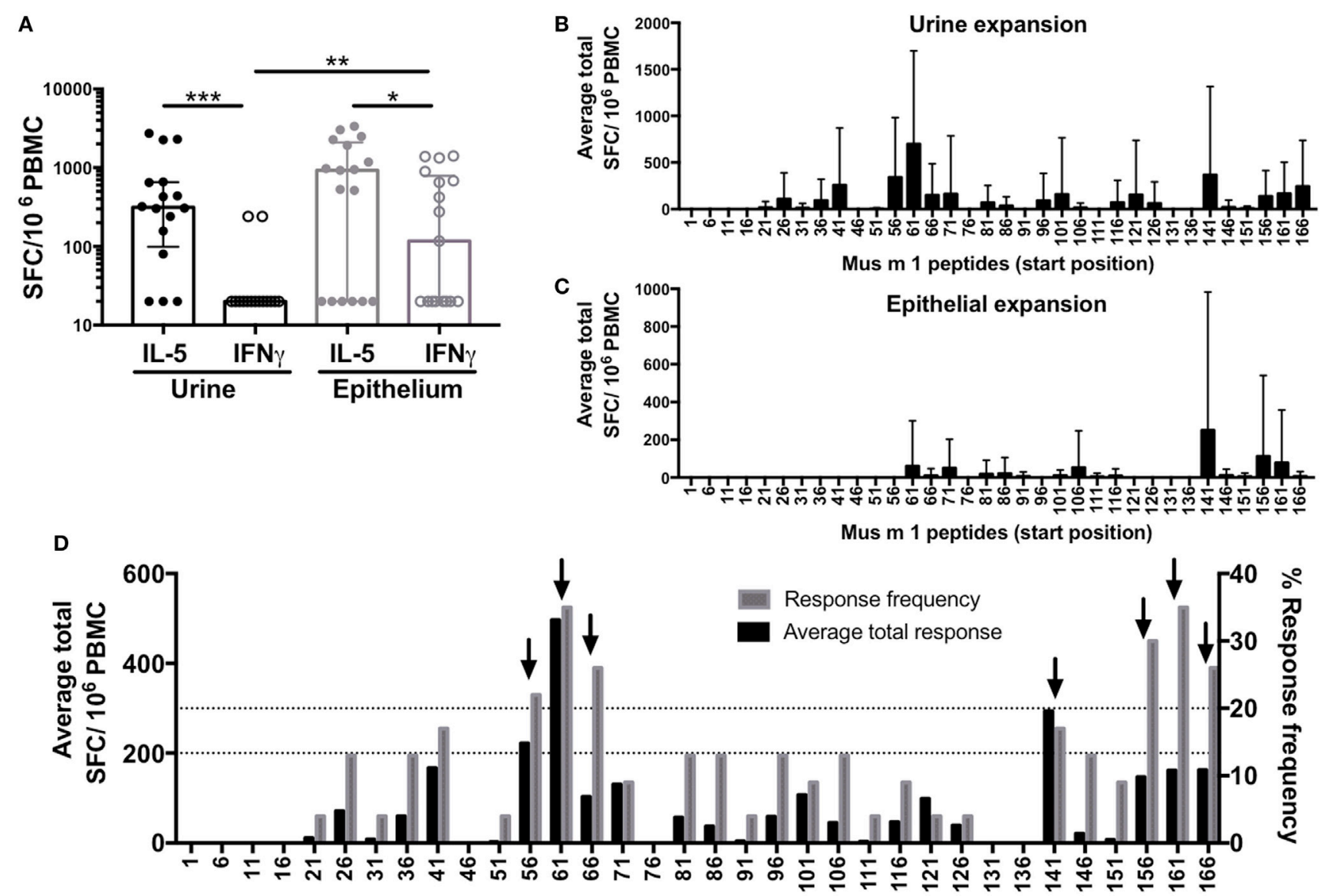

Mus $\mathrm{m} 1$ peptides (start position)

FIGURE 1 | Allergic T cell responses to mouse urine and epithelial extract and the major allergen Mus $m$ 1. Cytokine production was measured by ELISPOT following in vitro restimulation with (A) urine or epithelial extract; or overlapping 15-mer peptides spanning Mus $\mathrm{m} 1$ after in vitro culture with (B) urine or (C) epithelial extract. Error bars indicate SDs. (D) Data from Mus $\mathrm{m}$ 1-derived peptide responses after urine and epithelial expansion were combined to identify immunodominant peptides [frequency $\geq 20 \%$; magnitude $\geq 200$ spot-forming cells (SFC)], indicated by black arrows. Responses below detection threshold were set to 20 SFC. Statistical analysis was performed by Wilcoxon signed rank test (paired), one-tailed comparison for IL-5 vs. IFN $\gamma$, and Mann-Whitney test (unpaired), two-tailed comparison for IFN $\gamma$ vs. IFN $\gamma .{ }^{*} p<0.05,{ }^{* \star} p<0.01$, and ${ }^{\star \star *} p<0.001$.
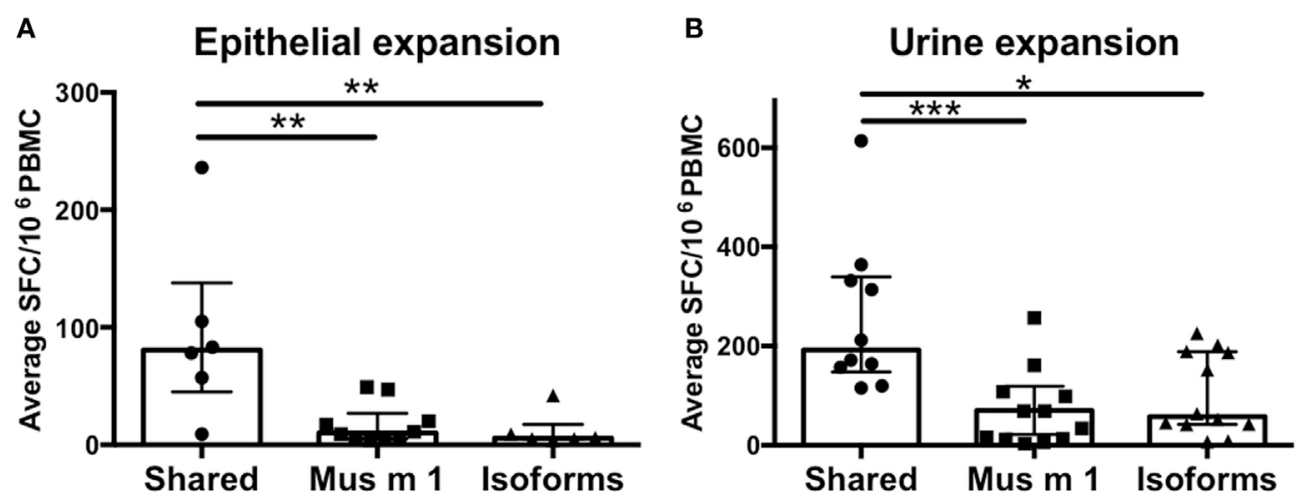

FIGURE 2 | T cell reactivity against conserved vs. non-conserved major urinary protein (MUP) peptides. Cytokine production (IL-5 + IFN $\gamma$ ) was measured as spot forming cells (SFC) by ELISPOT in response to Mus m 1-unique, other MUP isoforms-unique, or conserved (shared) peptides after expansion with (A) epithelial extract or (B) mouse urine. Statistical analysis was performed by Mann-Whitney test, one-tailed. ${ }^{*} p<0.05,{ }^{* *} p<0.01$, and ${ }^{* * *} p<0.001$. 
to increased/repeated exposures by the various homologous allergen species.

\section{T Cell Reactivity against MO Orthologs of Allergens from Other Mammals}

Several allergens have been described in other mammalian species, such as horses, cattle, rabbits, guinea pigs, hamsters, cats and dogs. In most cases, these proteins have mouse orthologs. Here we hypothesized that at least some of these mouse orthologs could also have allergenic potency. To address this issue, we tested 244 predicted HLA class II binding peptides from orthologs to 20 known mammalian allergens derived from 7 different animals (Table S2 in Supplementary Material). To determine whether $\mathrm{T}$ cell reactivity detected against the mouse sequences was due to cross-reactivity between the mouse and homologous mammalian sequence, we also tested in parallel, for each peptide, the corresponding peptide from the originally described mammalian allergen.

Out of a total of 244 peptide pairs tested, responses were detected against $61 \mathrm{MO}$-derived peptides from 12/20 mouse orthologs of known mammalian allergens (Figures 3A,B). A strong bias was observed for urine extract to expand lipocalin-specific $\mathrm{T}$ cells
(Figure 3A), while stimulation with epithelial extract expanded mostly albumin and kallikrein-specific $\mathrm{T}$ cells (Figure 3B). Actual cross-reactive recognition (reactivity against both the mouse peptide and its mammalian homolog) was only detected in a single case, namely Cav p 6, the albumin from guinea pig and its mouse homolog (Figure 3A), suggesting that the majority of these proteins are bona-fide mouse T cell antigens. Furthermore, some $\mathrm{T}$ cell responses against mammalian peptides in absence of reactivity to the mouse homolog were also observed, targeting 13 peptides from 3 allergens (Bos d 5, Cav p 4 Equ c 4), suggesting that in these cases, donors may be polysensitized against $\mathrm{MO}$ and other animal allergens. In conclusion, these data identified several novel mouse antigens targeted by $\mathrm{T}$ cells, based on the fact that their orthologs in other mammalian species were known allergens.

\section{A Global View of Immunodominance in MO Responses}

To broadly define additional potential murine antigens, we followed a previously described immunoproteomic approach $(18,23)$. As described in the methods, peptides predicted from proteins identified based on their IgE and IgG-reactivity profile from $2 \mathrm{D}$ immunoblots were screened for $\mathrm{T}$ cell reactivity after
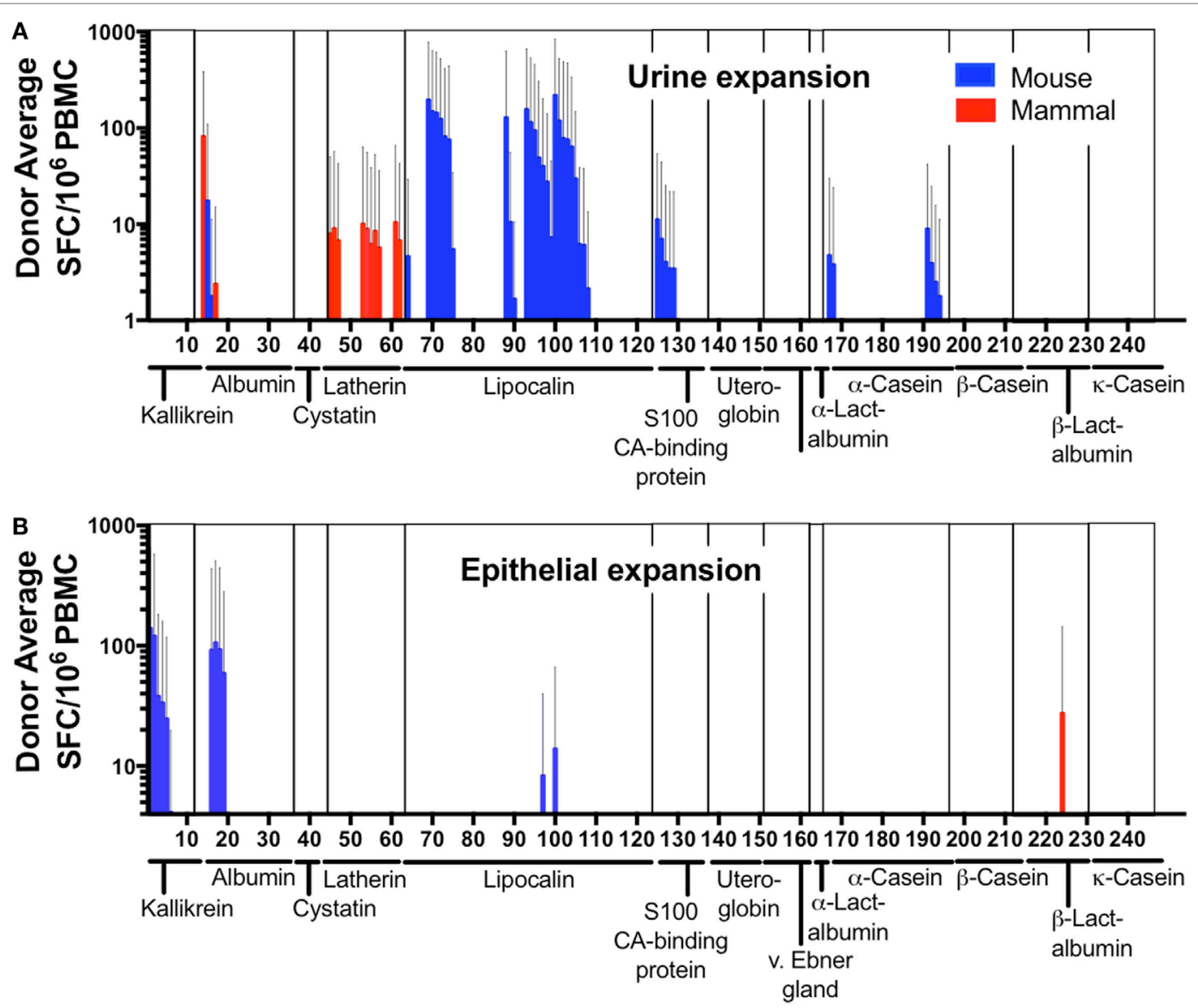

FIGURE 3 | T cell reactivity against mammalian allergens and their murine homologs. Cytokine production (IL-5 + IFN $\gamma$ ) was measured as spot forming cells by ELISPOT in response to mammalian-allergen-derived peptides and their homologous murine counterpart after expansion with (A) mouse urine or (B) epithelial extract. Allergen families are indicated along the $x$-axis. Error bars indicate SDs. 
urine and epithelial extract expansion. Epithelial extract stimulation expanded $\mathrm{T}$ cells reactive to peptides from 4 out of 23 novel proteins identified from 2D immunoblot analysis of epithelial extract (Figure 4). These proteins included Alpha-amylase [a known allergen cockroach $(29,30)$ among others $(31)]$ and two fragments of the murine Ig kappa chain. No reactivity was observed against any further novel proteins obtained from urine 2D immunoblot analysis, regardless of culture stimulus. Thus, the immunoproteomic analysis revealed relatively few additional novel T cell targets.

Based on this comprehensive set of data, we analyzed the patterns of $\mathrm{T}$ cell immunodominance in mouse allergy. After elimination of redundant peptides with $\geq 70 \%$ identity using the clustering tool (Dhanda et al., submitted), a total of 106 epitopes were recognized (see complete list in Table S4A in Supplementary Material). The top 26 epitopes account for $75 \%$ of the response, and the top 40 epitopes make up $90 \%$ of the total response. At the antigen level, $79 \%$ of total response is accounted for by Lipocalinrelated proteins (Table S4B in Supplementary Material) with Mus $\mathrm{m} 1$ alone accounting for $27 \%$ of the total response, making it the most dominantly recognized $\mathrm{T}$ cell antigen. The top 7 antigens (out of 35 in total) account for $\sim 75 \%$ of the response, and of those, 5 are Lipocalins. Similarly, out of 12 antigens accounting for $90 \%$ of the response, 9 are Lipocalins.

\section{HLA Restriction Predictions Using RATE}

The issue of which HLA restriction is associated with a given epitope is of considerable interest. HLA types of all donors included in this study were determined by HLA typing (Table S5 in Supplementary Material). A genetic inference method, named restrictor analysis tool for epitopes (RATE) (25), was used to infer HLA restriction of epitopes from $\mathrm{T}$ cell response data in HLA typed subjects. While the inferred restrictions here are based on a limited set of donors $(n=22)$, nevertheless it appears that all four HLA class II loci (DRB1; DRB3, DQ, and DP) appear to be restricting responses (Table 2). These patterns of inferred HLA restriction should be interpreted with caution, since the small number of donors analyzed limits the power of HLA restriction assignments based on genetic inference. We expect that as data relating to more donors becomes available, more genetic associations, relating to more allelic variants will become apparent, especially as it relates to promiscuous restriction to several HLA class II molecules.

\section{Differences in Antigen-Recognition But Not Magnitude or Polarization Differentiate Asthmatic vs. Rhinitic T Cell Responses}

In the German cockroach allergy system (18) different clinical phenotypes are associated with different $\mathrm{T}$ cell response magnitude and epitope specificity, and these differences can be used to discriminate asthmatic patients from non-asthmatic, allergic rhinitis patients. To determine if similar differences in $\mathrm{T}$ cell specificity are also observed in mouse allergy, we separately analyzed asthmatic $(n=13)$ and non-asthmatic, rhinitis donors $(n=7)$ (Table 1) (one donor was unresponsive to all dominant 106 epitopes, one donor was of unknown disease status). At the individual patient level, no difference in response magnitude against single epitopes was observed (Figure 5A). However, when comparing the breadth of epitope reactivity (number of epitopes recognized), asthmatic patients had an increased breadth of response compared to rhinitic patients (Figure 5B). Both asthmatic and rhinitc responses were strongly IL-5-polarized (Figure 5C), consistent with observations of whole extract $\mathrm{T}$ cell reactivity (Figure 1A). Asthmatic donor responses were more diverse compared to rhinitic donor responses (33 vs. 12 antigens, respectively; overlap of 10 antigens) (Figure 5D). Ten antigens elicited $\mathrm{T}$ cell reactivity in both cohorts, accounting for $73 \%$ of the total response in asthmatics and 58\% in rhinitc patients

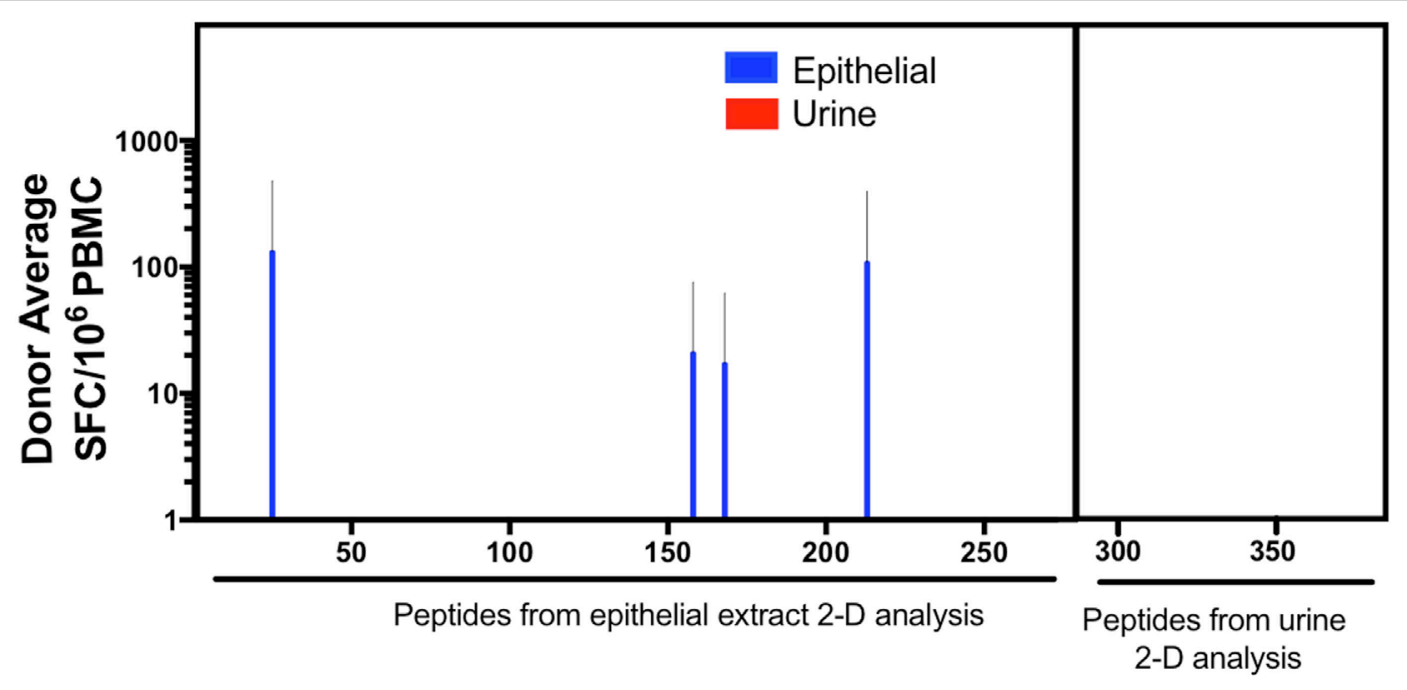

FIGURE 4 | T cell responses against previously undescribed lgG and lgE-reactive mouse proteins. Cytokine production (IL-5 + IFN $\gamma$ ) was measured as spot forming cells (SFC), by ELISPOT in response to predicted peptides derived from immunoproteomic analysis of mouse urine and epithelium. Error bars indicate SDs. 
TABLE 2 | Inferred HLA allele restriction analysis performed using the RATE analysis tool.

\begin{tabular}{|c|c|c|c|c|c|c|c|c|c|c|c|c|}
\hline Antigen & Peptide seq & Allele\# & Allele & $\mathbf{A}+\mathbf{R}+$ & $\mathbf{A}-\mathbf{R}+$ & $\mathbf{A}+\mathbf{R}-$ & A-R- & $\begin{array}{l}\text { No. of } \\
\text { donors }\end{array}$ & $\begin{array}{l}\text { Relative } \\
\text { freq }\end{array}$ & $\begin{array}{l}\text { Odds } \\
\text { ratio }\end{array}$ & $p$-Value & $\begin{array}{c}\text { \%ile } \\
\text { binding }\end{array}$ \\
\hline Mus m 1 & FRLFLEQIHVLENSL & 32 & $\mathrm{DQB1}{ }^{*} 05: 01$ & 4 & 1 & 2 & 15 & 22 & 2.9 & 30 & 0.0093 & 5.11 \\
\hline Mus m 1 & EPDLSSDIKERFAQL & 42 & DRB1*03:01 & 3 & 1 & 1 & 17 & 22 & 4.1 & 51 & 0.0100 & 0.18 \\
\hline Mus m 1 & EPDLSSDIKERFAKL & 42 & DRB1*03:01 & 3 & 0 & 1 & 18 & 22 & 5.5 & $\operatorname{lnf}$ & 0.0026 & 0.17 \\
\hline MUP 14 & EEASSTGRNFNVEKINGEWHTII & 61 & $\mathrm{DRB3}^{*} 01: 01$ & 3 & 0 & 2 & 17 & 22 & 4.4 & $\operatorname{lnf}$ & 0.0065 & 16.48 \\
\hline MUP 13 & GLYGREPDLSSDIKERFA & 42 & DRB1*03:01 & 3 & 0 & 1 & 18 & 22 & 5.5 & $\operatorname{lnf}$ & 0.0026 & 0.59 \\
\hline MUP 11 & GKYSVTYDGFNTFTI & 8 & DPB1*04:02 & 3 & 1 & 0 & 18 & 22 & 5.5 & $\operatorname{lnf}$ & 0.0026 & 17.35 \\
\hline
\end{tabular}

$p<0.05$ is considered significant.

$A$, allele; $R$, responder; $R F$, relative frequency; $O R$, odds ratio.
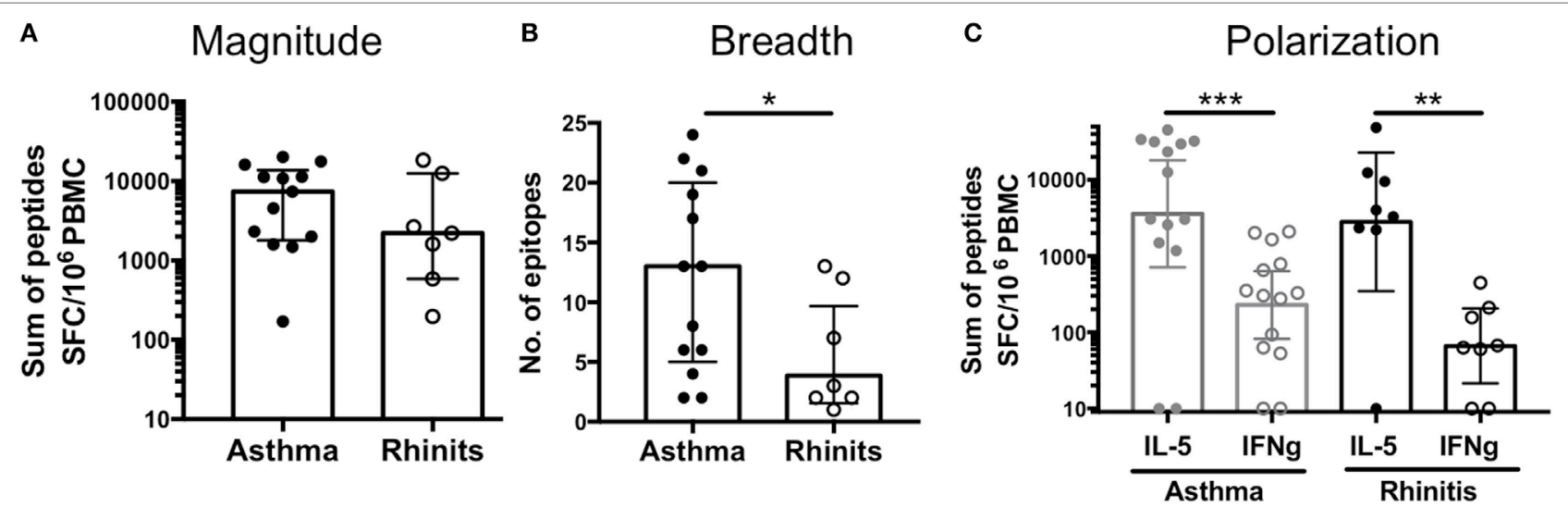

D
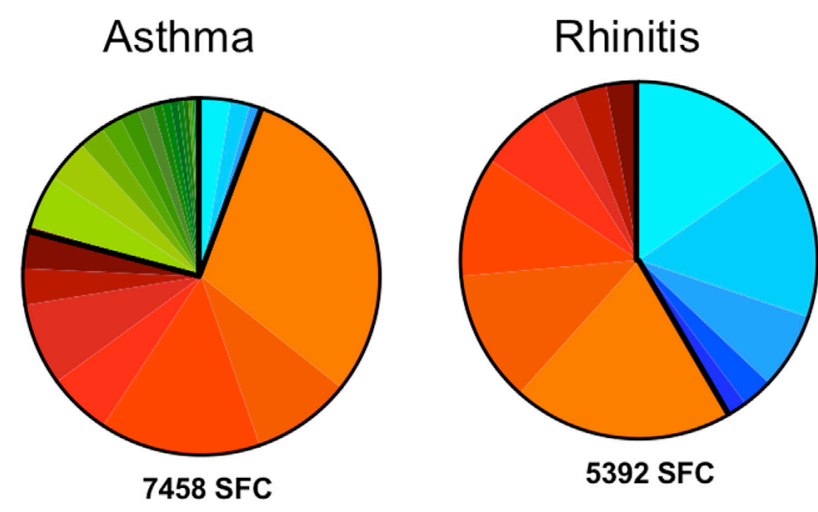

Blue- Rhinitis

Red- Shared
Green-Asthma
$\square$ Kallikrein 1 peptidase
$\square$ BAC34145.1
$\square$ Odorant binding protein 1
$\square$ Alpha-amylase
$\square$ Beta-globin
$\square$ Mus m 1
$\square$ MUP 4
$\square$ MUP IV Complex
$\square$ MUP 1
$\square$ MUP 13.01
$\square$ MUP 26

$\square$ MUP 25
MUP 5
$\square$ MUP 24
$\square$ Cadherin 1
MUP 11
Odorant-binding protein 2a
Ig kappa chain V-III PC 7175
S100-A15A
Fab 7d11 Chain A
Ig kappa chain V-V
Alpha-S2-casein
$\square$ Alpha-S1-casein
$\square$ MUP 3
$\square$ Ig kappa chain V-III MOPC 70
$\square$ Kidney androgen-regulated protein
$\square$ Cathepsin S
$\square$ Odorant binding protein Ib
$\square$ Ig kappa chain V-III 50S10.1
Vomeronasal secretory protein 1

FIGURE 5 | Differences in T cell reactivity in asthmatic versus rhinitic donors. (A) Response magnitude, (B) breadth of response, (C) cytokine polarization and (D) antigen immunodominance were assessed in asthmatic $(n=13)$ and rhinitic $(n=7)$ donors. Antigens predominantly recognized in asthmatic donors are shown in green, antigens recognized by both cohorts are shown in red and antigens predominantly recognized by rhinitic donors are shown in blue. Statistical analysis was performed by Mann-Whitney test, one-tailed. ${ }^{*} p<0.05,{ }^{* *} p<0.01$, and ${ }^{* *} p<0.001$.

(Figure 5D). The other antigens were rather selectively recognized in either asthmatic or rhinitic donors. Rhinitc donors exhibited a more focused response, with $42 \%$ of it targeting 5 antigens (Kallikrein, BAC34145, Odorant binding protein, Alpha-amylase and Beta-goblin) that made up less than $6 \%$ of the reactivity in the asthmatic cohort. In parallel we noted that $21 \%$ of the T cell response in asthmatics targeted antigens that were not recognized at all by rhinitic patients (Figure 5D).

\section{An Epitope Megapool as a Tool to Study Mouse-Specific T Cell Responses Ex Vivo}

Characterizing allergen-specific $\mathrm{T}$ cell responses ex vivo is challenging because the frequency of these cells in peripheral blood is often at the limit of detection. We previously demonstrated that allergen-specific $\mathrm{T}$ cells are detectable ex vivo using pools of dominant T cell epitopes (32) in the House Dust Mite system. Following the same approach, we created a mouse allergy epitope 
megapool, consisting of 106 dominant T cell epitopes identified herein, and assessed its ability to elicit $\mathrm{T}$ cell reactivity directly ex vivo in cells from 12 mouse allergic patients (6 rhinitic, 6 asthmatic), for whom we had sufficient cells left. Using the upregulation of the activation marker CD154 (CD40L) as a read-out for T cell reactivity, we used the previously published Antigen-Reactive T cell Enrichment assay (27) to detect mouse-specific T cells after short-term stimulation with epithelial extract, urine extract or the epitope megapool. In addition, intracellular cytokine staining was performed, amending the previous assessment of cytokine production from IL-5 and IFN $\gamma$ to assessing production of IL-4, IFN $\gamma$, IL-17, and IL-10 (Figure 6A) to determine if different patterns of cytokine production are associated with asthmatics or rhinitic disease status. IL-5 was not measured ex vivo, as in our experience its detection by flow cytometry is far inferior compared to ELISPOT.

Stimulation with the megapool successfully elicited epitopespecific $\mathrm{T}$ cell activation $>2$-fold above background (medium alone) in 11 out of 12 donors, whereas only $1 / 12$ and $2 / 12$ donors were reactive after stimulation with urine and epithelial extract, respectively (Figure 6B). These data suggest that stimulation with the top $\mathrm{T}$ cell epitopes greatly improves the detection of low-frequency mouse-specific T cells ex vivo, which are largely undetected after extract stimulation.
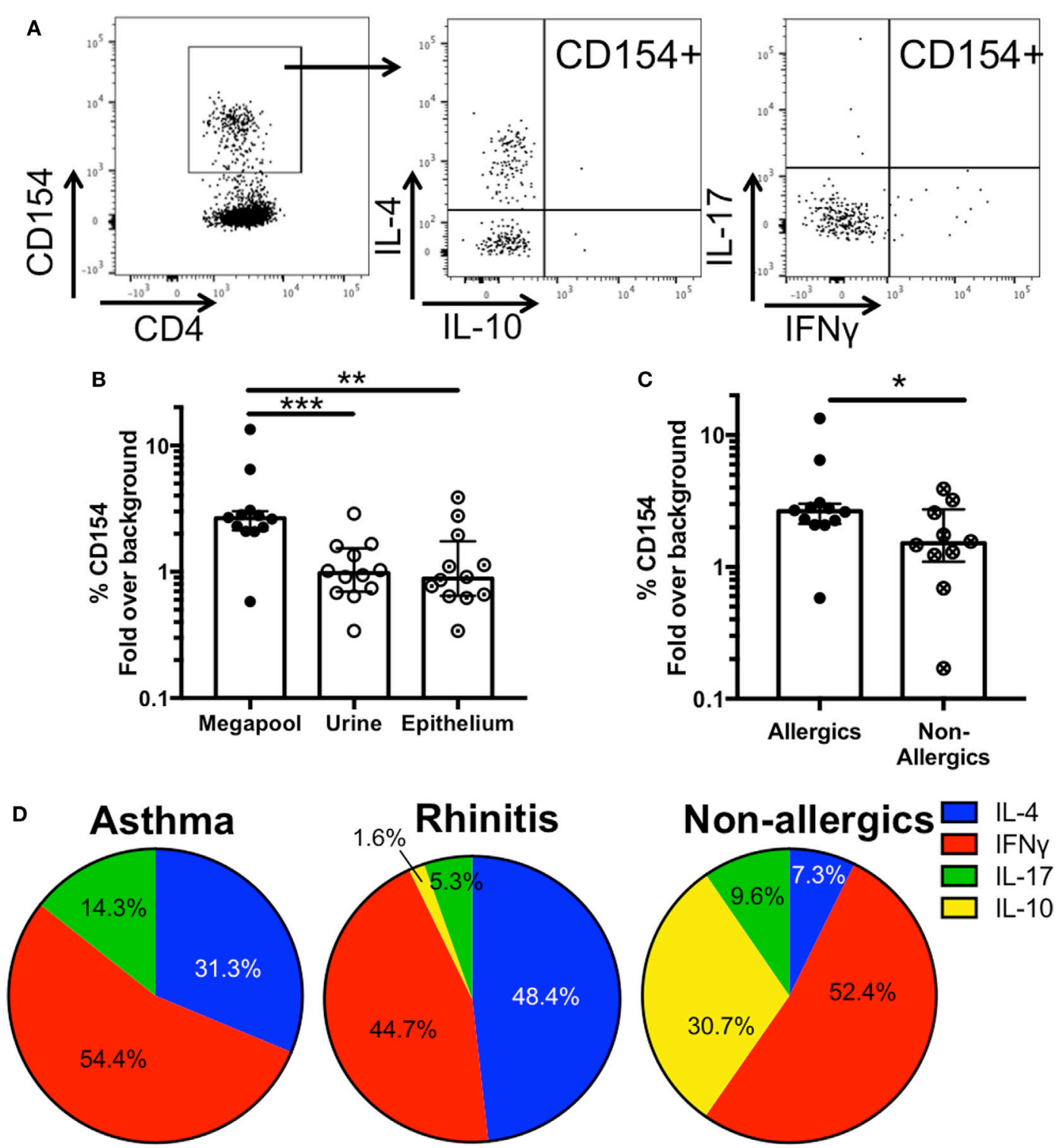

FIGURE 6 | Ex vivo T cell activation and cytokine production in response to mouse antigen. (A) Representative FACS plots showing CD154+ cells and intracellular cytokine staining in activated cells after megapool stimulation (B) Ex vivo T cell activation in response to mouse epitope megapool or extract stimulation was assessed based on CD154 expression $(n=12)$. Wilcoxon test (one-tailed) was used for statistical analysis. (C) Ex vivo T cell activation in response to mouse epitope megapool in mouse allergic $(n=12)$ and non-allergic individuals $(n=10)$. Mann-Whitney test (one-tailed) was used for statistical analysis. (D) Patterns of cytokine production in antigen-specific (CD154+) T cells in asthmatic $(n=6)$, rhinitic $(n=6)$, and non-allergic $(n=10)$ donors. ${ }^{*} p<0.05,{ }^{\star *} p<0.01$, and ${ }^{\star \star *} p<0.001$. 
Analysis of the average cytokine production in CD154+ $\mathrm{T}$ cells revealed that responses were dominated by IFN $\gamma$ and IL-4 in both asthmatic and rhinitic patients (Figure 6B; Table S6 in Supplementary Material). However, $14.3 \%$ of the total cytokine response in asthmatics was accounted for by IL-17, which was almost threefold lower (5.3\%) in rhinitic patients. IL-10 made up less than $2 \%$ of the total cytokine production in rhinitic patients and was totally absent in asthmatics (Figure 6D). To assess whether the epitope megapool is preferentially recognized in allergic as opposed to non-allergic donors, cells from $10 \mathrm{MO}$ non-allergic donors, who are exposed to mice every day due to occupation, were also assessed. Ex vivo T cell activation to the mouse megapool was significantly lower in allergics compared to non-allergics ( $p=0.02$ ) (Figure 6C). Furthermore, non-allergic individuals exhibited a very different cytokine profile, dominated by IFN $\gamma$ and IL-10 and very little IL-4 and IL-17 (Figure 6D).

\section{DISCUSSION}

Despite its clinical importance, little is known about the human allergic immune response to mouse antigens, especially on the $\mathrm{T}$ cell level. To the best of our knowledge, this is the first study focused on mouse-specific $T$ cell responses in mouse-sensitized asthmatic and rhinitic patients. We found that Mus $\mathrm{m} 1$ (lypocalin) and serum albumin are strongly dominant antigens at the $\mathrm{T}$ cell level, with Mus1 being dominant in particular in urine extract and albumin more represented in the epithelial extract. A more in depth analysis revealed that sequence conservation across lypocalins played an important role in determining immunodominance. Our studies also revealed several minor T cell antigens, mostly identified through screening of orthologs of reported mammalian allergens and, in very few cases by immunoproteomic analysis of 2D immunoblots of mouse extracts. Interestingly, the $\mathrm{T}$ cell response specificity differed depending on clinical phenotype, with mouse-sensitized asthmatic and rhinitic patients recognizing only partially overlapping sets of antigens.

It has to be mentioned that the protein extracts and peptides were not subject to extensive purification, therefore some responses may have been affected by endotoxins present in the materials. However, not all extracts and peptides elicited responses in all cultures suggesting that non-specific reactivity did not influence our findings in a major way.

The use of epithelial extract in the diagnosis of mouse allergy has been a matter of debate in the field due to its low and variable amounts of Mus m 1, the only known major mouse allergen. For this reason, a previous study (33) investigated the diagnostic utility of mouse urine and compared it to the performance of commercial epithelial extract. They reported both extracts to be of comparative diagnostic performance, suggesting in addition to Mus $\mathrm{m}$ 1, other proteins such as albumin may also be important triggers for clinical symptoms to mice. This is in line with our finding that both extracts are comparable in the stimulation of MO-allergen-specific T cells.

We identified seven immunodominant epitopes from Mus $\mathrm{m} 1$, the only known mouse allergen registered in the IUIS database (14). To the best of our knowledge, only one Mus m 1-derived T cell epitope had been reported to date (20), which largely overlaps with one of our seven dominant $\mathrm{T}$ cell epitopes (Mus $\mathrm{m} 1_{141}$ ). When we extended our T cell epitope mapping efforts beyond Mus $\mathrm{m}$ 1, investigating peptides from Mus $\mathrm{m} 1$ isoforms, mammalian allergen orthologs and protein targets identified by immune-proteomic analysis of mouse urine and epithelial extract, we found that Mus $\mathrm{m} 1$ alone accounted for $27 \%$ of the total $\mathrm{T}$ cell response, confirming the dominant role of this allergen in mouse allergy. Further extending this analysis to consider other members of the lipocalin superfamily (Mus $\mathrm{m}$ 1 isoforms and mammalian homologs) revealed that lipocalins accounted for $79 \%$, while other T cell-reactive antigens, including serum albumin, only made up $21 \%$ of the response. These data suggest that the mouse allergic $\mathrm{T}$ cell response is very focused, potentially making it an attractive model system for single allergen or even peptide-based immunotherapy approaches. However, it is important to mention that this screen was limited to IL-5 and IFN $\gamma$ production, therefore epitopes eliciting exclusively other cytokine responses such as IL-10 or IL-17 will not have been detected.

The impact of sequence conservation on immunodominance has been reported in many different systems, including grass pollen allergy $(28)$, viral infection $(34,35)$ and tuberculosis $(36)$. Mus $\mathrm{m} 1$ is part of an allergen family that is highly conserved among several mammalian species. An analysis of the impact of sequence homology on Mus $\mathrm{m}$ 1-specific $\mathrm{T}$ cell reactivity revealed that peptides that are shared between Mus $\mathrm{m} 1$ and other MUPs are significantly more $\mathrm{T}$ cell-reactive, suggesting that also in mouse allergy, sequence conservation ultimately boosts $\mathrm{T}$ cell responses, presumably due to increased frequency of exposure.

Screening orthologs of reported mammalian allergens revealed several additional $\mathrm{T}$ cell antigens, showing that a systematic ortholog approach can be used to screen for $\mathrm{T}$ cell targets in mammals. Conversely, the immunoproteomic approach, previously applied to cockroaches, pollens and house dust mites $(18,23,37)$ yielded only few hits. The reasons for this are not clear but might be related to the immunodominance of lypocalins, as discussed above.

Sensitization to mouse is strongly associated with wheezing in children and asthma in adults, however, some mouse-allergic patients never develop any asthmatic symptoms. Here we found no difference in magnitude of responses, but rather we uncovered that the breadth of response, both at the antigen and epitope level, is significantly higher in asthmatics compared to rhinitis, which was focused on fewer but potentially more dominant antigens. Interestingly, the $\mathrm{T}$ cell response specificity in mouse-sensitized asthmatic and rhinitic patients only partially overlapped, as the cohorts shared recognition of 10 of the 35 T cell-reactive antigens. A similar difference in the antigens recognized by asthmatic versus rhinitis patients was noted in CR-allergic donors (18). The mechanism underlying these observations is not clear, but it might be related to cosensitization and cross-reactivity to other allergens in these cohorts.

Finally, we assessed whether the most dominant $\mathrm{T}$ cell epitopes could be used as a tool to facilitate the detection and phenotypic characterization of mouse-specific T cells directly 
ex vivo. Using the upregulation of the $\mathrm{T}$ cell activation marker CD154 as a read-out, we found that mouse-specific T cells could be detected in $>90 \%$ of donors, whereas urine or epithelium extract stimulation only triggered CD154 expression in 8.3 and $16.6 \%$ of donors, respectively. Moreover, analysis of cytokine production in CD154+ T cells of asthmatic and rhinitic patients revealed that, while both cohorts predominantly express IFN $\gamma$ and IL-4, asthmatics produce almost three times more IL-17 on average. This is consistent with studies suggesting a central role for IL-17 in asthma based on levels in sputum and tissue biopsies from asthmatic patients (38). Of note, ex vivo responses appear to be less dominated by Th2 cytokines compared to $\mathrm{T}$ cell reactivity after expansion measured by ELISPOT. The reason for this is not fully clear, however, it may be related to the fact that the different assays exhibit different sensitivity for IFN $\gamma$ detection or that the 14-day culture environment favors Th2 proliferation.

Interestingly, comparison of ex vivo $\mathrm{T}$ cell activation in allergic and non-allergic donors revealed a significantly decreased reactivity in non-allergics, associated with a Th1/Tr1 dominated cytokine production profile.

Sensitization to mice is an important risk factor for asthma development, yet very little data is available on the immunological targets recognized by the human immune system. Our investigation of $\mathrm{T}$ cell epitopes recognized in mouse allergy allowed the creation of an epitope megapool, which enables detection and phenotypic characterization of mouse-specific T cells directly ex vivo. These data provide a good basis for future studies to improve mouse allergy diagnostics and increase our understanding of the immunopathology associated with $\mathrm{MO}$-allergies.

\section{REFERENCES}

1. Phipatanakul W, Eggleston PA, Wright EC, Wood RA; National Coooperative Inner-City Asthma Study. Mouse allergen. II. The relationship of mouse allergen exposure to mouse sensitization and asthma morbidity in inner-city children with asthma. J Allergy Clin Immunol (2000) 106:1075-80. doi:10.1067/ mai.2000.110795

2. Phipatanakul W, Eggleston PA, Wright EC, Wood RA. Mouse allergen. I. The prevalence of mouse allergen in inner-city homes. The National Cooperative Inner-City Asthma Study. J Allergy Clin Immunol (2000) 106:1070-4. doi:10.1067/mai.2000.110796

3. Platts-Mills TA, Satinover SM, Naccara L, Litonjua AA, Phipatanakul W, Carter MC, et al. Prevalence and titer of IgE antibodies to mouse allergens. JAllergy Clin Immunol (2007) 120:1058-64. doi:10.1016/j.jaci.2007. 06.032

4. Aoyama K, Ueda A, Manda F, Matsushita T, Ueda T, Yamauchi C. Allergy to laboratory animals: an epidemiological study. Br J Ind Med (1992) 49:41-7.

5. Hollander A, Gordon S, Renstrom A, Thissen J, Doekes G, Larsson PH, et al. Comparison of methods to assess airborne rat and mouse allergen levels. I. Analysis of air samples. Allergy (1999) 54:142-9. doi:10.1034/j.1398-9995. 1999.00630.x

6. Donohue KM, Al-Alem U, Perzanowski MS, Chew GL, Johnson A, Divjan A, et al. Anti-cockroach and anti-mouse IgE are associated with early wheeze and atopy in an inner-city birth cohort. J Allergy Clin Immunol (2008) 122:914-20. doi:10.1016/j.jaci.2008.08.034

7. Sheehan WJ, Rangsithienchai PA, Wood RA, Rivard D, Chinratanapisit S, Perzanowski MS, et al. Pest and allergen exposure and abatement in inner-city asthma: a work group report of the American Academy of Allergy, Asthma \& Immunology Indoor Allergy/Air Pollution Committee. JAllergy Clin Immunol (2010) 125:575-81. doi:10.1016/j.jaci.2010.01.023

\section{ETHICS STATEMENT}

Patients were recruited from San Diego, CA, and New York City, NY. following Institutional Review Board approval (IRB protocols: VD-112-0217, GCO 13-0691). All patients enrolled in this study provided written consent.

\section{AUTHOR CONTRIBUTIONS}

LW and GB: experimental design and performance. SP: bioinformatical analyses. PB: clinical sample collection and preparation and scientific input. JS: peptide manufacture and scientific input. VS, BP, and AS: project conception, planning, experimental design, data analysis, and manuscript preparation.

\section{ACKNOWLEDGMENTS}

We thank David and Deborah Broide for provision of clinical samples. This work was supported in whole or in part with Federal funds from the National Institute of Allergy and Infectious Diseases, National Institutes of Health, Department of Health and Human Services, under contract numbers HHSN272200900052C and HHSN272201000052I and grant numbers 1UM1AI114271, U19AI100275 and U19AI135731.

\section{SUPPLEMENTARY MATERIAL}

The Supplementary Material for this article can be found online at http://www.frontiersin.org/articles/10.3389/fimmu.2018.00235/ full\#supplementary-material.

8. Lincoln TA, Bolton NE, Garrett AS Jr. Occupational allergy to animal dander and sera. J Occup Med (1974) 16:465-9.

9. Siraganian RP, Sandberg AL. Characterization of mouse allergens. J Allergy Clin Immunol (1979) 63:435-42. doi:10.1016/0091-6749(79)90219-7

10. Hook WA, Powers K, Siraganian RP. Skin tests and blood leukocyte histamine release of patients with allergies to laboratory animals. J Allergy Clin Immunol (1984) 73:457-65. doi:10.1016/0091-6749(84)90355-5

11. Taylor AN, Longbottom JL, Pepys J. Respiratory allergy to urine proteins of rats and mice. Lancet (1977) 2:847-9. doi:10.1016/S0140-6736(77)90783-8

12. Levy DA. Allergenic activity of proteins from mice. Int Arch Allergy Appl Immunol (1975) 49:219-21. doi:10.1159/000231399

13. Shaw $\mathrm{PH}$, Held WA, Hastie ND. The gene family for major urinary proteins: expression in several secretory tissues of the mouse. Cell (1983) 32:755-61. doi:10.1016/0092-8674(83)90061-2

14. Marsh DG, Goodfriend L, King T, Lowenstein H, Platts-Mills T. Allergen Nomenclature [Online]. Bull World Health Organ (1986). Available at: http:// www.allergen.org/index.php

15. Chapman MD, Smith AM, Vailes LD, Arruda LK, Dhanaraj V, Pomes A. Recombinant allergens for diagnosis and therapy of allergic disease. J Allergy Clin Immunol (2000) 106:409-18. doi:10.1067/mai.2000.109832

16. Mudge JM, Armstrong SD, Mclaren K, Beynon RJ, Hurst JL, Nicholson C, et al. Dynamic instability of the major urinary protein gene family revealed by genomic and phenotypic comparisons between C57 and 129 strain mice. Genome Biol (2008) 9:R91. doi:10.1186/gb-2008-9-5-r91

17. Jeal H, Draper A, Harris J, Taylor AN, Cullinan P, Jones M. Determination of the $\mathrm{T}$ cell epitopes of the lipocalin allergen, Rat n 1. Clin Exp Allergy (2004) 34:1919-25. doi:10.1111/j.1365-2222.2004.02126.x

18. Dillon MB, Schulten V, Oseroff C, Paul S, Dullanty LM, Frazier A, et al. Different Bla-g $\mathrm{T}$ cell antigens dominate responses in asthma versus rhinitis subjects. Clin Exp Allergy (2015) 45:1856-67. doi:10.1111/cea.12643 
19. Vita R, Overton JA, Greenbaum JA, Ponomarenko J, Clark JD, Cantrell JR, et al. The immune epitope database (IEDB) 3.0. Nucleic Acids Res (2015) 43:D405-12. doi:10.1093/nar/gku938

20. Ferrari E, Breda D, Longhi R, Vangelista L, Nakaie CR, Elviri L, et al. In search of a vaccine for mouse allergy: significant reduction of Mus $\mathrm{m} 1$ allergenicity by structure-guided single-point mutations. Int Arch Allergy Immunol (2012) 157:226-37. doi:10.1159/000327551

21. Tamura K, Stecher G, Peterson D, Filipski A, Kumar S. MEGA6: molecular evolutionary genetics analysis version 6.0. Mol Biol Evol (2013) 30:2725-9. doi:10.1093/molbev/mst197

22. Paul S, Lindestam Arlehamn CS, Scriba TJ, Dillon MB, Oseroff C, Hinz D, et al. Development and validation of a broad scheme for prediction of HLA class II restricted T cell epitopes. J Immunol Methods (2015) 422:28-34. doi:10.1016/j.jim.2015.03.022

23. Schulten V, Greenbaum JA, Hauser M, Mckinney DM, Sidney J, Kolla R, et al. Previously undescribed grass pollen antigens are the major inducers of $\mathrm{T}$ helper 2 cytokine-producing T cells in allergic individuals. Proc Natl Acad Sci US A (2013) 110:3459-64. doi:10.1073/pnas.1300512110

24. Pham J, Oseroff C, Hinz D, Sidney J, Paul S, Greenbaum J, et al. Sequence conservation predicts $\mathrm{T}$ cell reactivity against ragweed allergens. Clin Exp Allergy (2016) 46:1194-205. doi:10.1111/cea.12772

25. Paul S, Arlehamn CSL, Schulten V, Westernberg L, Sidney J, Peters B, et al. Experimental validation of the RATE tool for inferring HLA restrictions of T cell epitopes. BMC Immunol (2017) 18:20. doi:10.1186/s12865-017-0204-1

26. Oseroff C, Sidney J, Kotturi MF, Kolla R, Alam R, Broide DH, et al. Molecular determinants of $\mathrm{T}$ cell epitope recognition to the common Timothy grass allergen. J Immunol (2010) 185:943-55. doi:10.4049/jimmunol.1000405

27. Bacher P, Heinrich F, Stervbo U, Nienen M, Vahldieck M, Iwert C, et al. Regulatory $\mathrm{T}$ cell specificity directs tolerance versus allergy against aeroantigens in humans. Cell (2016) 167:1067.e-78.e. doi:10.1016/j.cell.2016.09.050

28. Westernberg L, Schulten V, Greenbaum JA, Natali S, Tripple V, Mckinney DM, et al. T-cell epitope conservation across allergen species is a major determinant of immunogenicity. J Allergy Clin Immunol (2016) 138(571-578):e577. doi:10.1016/j.jaci.2015.11.034

29. Saltzmann KD, Saltzmann KA, Neal JJ, Scharf ME, Bennett GW. Characterization of BGTG-1, a tergal gland-secreted alpha-amylase, from the German cockroach, Blattella germanica (L.). Insect Mol Biol (2006) 15:425-33. doi:10.1111/j.1365-2583.2006.00652.x

30. Jeong KY, Kim CR, Park J, Han IS, Park JW, Yong TS. Identification of novel allergenic components from German cockroach fecal extract by a proteomic approach. Int Arch AllergyImmunol (2013) 161:315-24.doi:10.1159/000347034
31. Houba R, Heederik DJ, Doekes G, Van Run PE. Exposure-sensitization relationship for alpha-amylase allergens in the baking industry. Am J Respir Crit Care Med (1996) 154:130-6. doi:10.1164/ajrccm.154.1.8680668

32. Hinz D, Oseroff C, Pham J, Sidney J, Peters B, Sette A. Definition of a pool of epitopes that recapitulates the $\mathrm{T}$ cell reactivity against major house dust mite allergens. Clin Exp Allergy (2015) 45:1601-12. doi:10.1111/cea. 12507

33. Norton A, Smith K, James K, Hoskins A, Scott TA, Plunkett G, et al. Diagnostic utility of concentrated Mus m 1 allergen extract in humans. Ann Allergy Asthma Immunol (2014) 112:391-2. doi:10.1016/j.anai.2014.01.024

34. Sridhar S, Begom S, Bermingham A, Hoschler K, Adamson W, Carman W, et al. Cellular immune correlates of protection against symptomatic pandemic influenza. Nat Med (2013) 19:1305-12. doi:10.1038/nm.3350

35. Weiskopf D, Angelo MA, De Azeredo EL, Sidney J, Greenbaum JA, Fernando AN, et al. Comprehensive analysis of dengue virus-specific responses supports an HLA-linked protective role for CD8+ T cells. Proc Natl Acad Sci U S A (2013) 110:E2046-53. doi:10.1073/pnas.1305227110

36. Lindestam Arlehamn CS, Paul S, Mele F, Huang C, Greenbaum JA, Vita R, et al. Immunological consequences of intragenus conservation of Mycobacterium tuberculosis T-cell epitopes. Proc Natl Acad Sci U S A (2015) 112:E147-55. doi:10.1073/pnas.1416537112

37. Oseroff C, Christensen LH, Westernberg L, Pham J, Lane J, Paul S, et al. Immunoproteomic analysis of house dust mite antigens reveals distinct classes of dominant $\mathrm{T}$ cell antigens according to function and serological reactivity. Clin Exp Allergy (2017) 47:577-92. doi:10.1111/cea.12829

38. Chesne J, Braza F, Mahay G, Brouard S, Aronica M, Magnan A. IL-17 in severe asthma. Where do we stand? Am J Respir Crit Care Med (2014) 190:1094-101. doi:10.1164/rccm.201405-0859PP

Conflict of Interest Statement: The authors declare that the research was conducted in the absence of any commercial or financial relationships that could be construed as a potential conflict of interest.

Copyright (c) 2018 Schulten, Westernberg, Birrueta, Sidney, Paul, Busse, Peters and Sette. This is an open-access article distributed under the terms of the Creative Commons Attribution License (CC BY). The use, distribution or reproduction in other forums is permitted, provided the original author(s) and the copyright owner are credited and that the original publication in this journal is cited, in accordance with accepted academic practice. No use, distribution or reproduction is permitted which does not comply with these terms. 